\title{
Codon harmonization reduces amino acid misincorporation in bacterially expressed P. falciparum proteins and improves their immunogenicity
}

\author{
Neeraja Punde ${ }^{1,3}$, Jennifer Kooken ${ }^{1}$, Dagmar Leary², Patricia M. Legler² and Evelina Angov*
}

\begin{abstract}
Codon usage frequency influences protein structure and function. The frequency with which codons are used potentially impacts primary, secondary and tertiary protein structure. Poor expression, loss of function, insolubility, or truncation can result from species-specific differences in codon usage. "Codon harmonization" more closely aligns native codon usage frequencies with those of the expression host particularly within putative inter-domain segments where slower rates of translation may play a role in protein folding. Heterologous expression of Plasmodium falciparum genes in Escherichia coli has been a challenge due to their AT-rich codon bias and the highly repetitive DNA sequences. Here, codon harmonization was applied to the malarial antigen, CelTOS (Cell-traversal protein for ookinetes and sporozoites). CelTOS is a highly conserved $P$. falciparum protein involved in cellular traversal through mosquito and vertebrate host cells. It reversibly refolds after thermal denaturation making it a desirable malarial vaccine candidate. Protein expressed in E. coli from a codon harmonized sequence of P. falciparum CelTOS (CH-PfCelTOS) was compared with protein expressed from the native codon sequence ( $\mathrm{N}$-PfCelTOS) to assess the impact of codon usage on protein expression levels, solubility, yield, stability, structural integrity, recognition with CelTOS-specific mAbs and immunogenicity in mice. While the translated proteins were expected to be identical, the translated products produced from the codon-harmonized sequence differed in helical content and showed a smaller distribution of polypeptides in mass spectra indicating lower heterogeneity of the codon harmonized version and fewer amino acid misincorporations. Substitutions of hydrophobic-to-hydrophobic amino acid were observed more commonly than any other. $\mathrm{CH}-$ PfCelTOS induced significantly higher antibody levels compared with N-PfCelTOS; however, no significant differences in either IFN- $\gamma$ or IL-4 cellular responses were detected between the two antigens.
\end{abstract}

Keywords: PfCelTOS, Codon-harmonization, Protein translation, Amino-acid misincorporation, Secondary structure, Alpha-helical content

\section{Introduction}

Escherichia coli expression systems have been widely used for the expression and manufacturing of various malarial antigens owing to their ease of use and advantages in cost and scale despite protein expression and folding obstacles. Common causes cited for poor

\footnotetext{
*Correspondence: evelina.angov.civ@mail.mil

${ }^{1}$ Malaria Biologics Branch, Walter Reed Army Institute of Research, Silver Spring, MD 20910, USA

Full list of author information is available at the end of the article
}

expression of recombinant genes in heterologous hosts are the species-specific disparities in codon usage. Codon usage frequencies can potentially impact a protein's function, solubility, and length (Khan et al. 2012).

In E. coli, protein folding can occur "co-translationally" at the ribosome (Komar 2009; Kramer et al. 2009; Nissley et al. 2016) and variable translation rates are thought to affect tertiary structure (Nissley et al. 2016). A recent study using genome-wide analysis provided evidence of evolutionary selection for co-translational folding, underscoring the importance of translation kinetics in 
protein folding (Jacobs and Shakhnovich 2017). More frequently used codons are often found in well-ordered structural elements such as alpha helices, while low usage frequency codons often occur within link/end segments (Thanaraj and Argos 1996). These observations suggest that codon usage frequency plays an inherent role in cotranslational folding.

Based on these concepts, we developed a strategy to "recode" target gene sequences for heterologous expression by substituting native codons with synonymous alternates with identical or similar usage frequencies in the expression host. This approach has been termed "codon harmonization", and applies a two-pronged approach. First, "best fit" codon usage frequency of the native gene is applied to that of the heterologous host. Second, putative link/end segments are identified and recoded to re-establish regions benefitted by slower translation (Angov et al. 2008).

We previously reported single base changes (i.e., FMP003 protein) for synonymous codon replacement can increase soluble protein yields by a factor of approximately ten, compared with native sequence yields (Angov et al. 2008). This protein was produced under cGMP conditions resulting in a highly immunogenic and efficacious product tested against malaria challenge in an Aotus monkey study (Darko et al. 2005). "Harmonizing" all of the codons throughout the gene sequence (i.e., FMP010 protein) yielded an additional 60 -fold increase in expression level (Angov et al. 2008). Furthermore, application of this approach to alternative alleles of $\mathrm{MSP}_{42}$ protein, yielded similar high levels of expression. The successes achieved are notable, because some native $P$. falciparum gene sequences expressed in $E$. coli yield no or low yields of recombinant protein (Angov et al. 2008). Here we applied codon harmonization to improve protein expression, yield, and quality of a novel malaria vaccine candidate, PfCelTOS.

"Cell-traversal protein for ookinetes and sporozoites" (CelTOS) is an essential protein in malaria parasites that is required for cell traversal in both mammalian and insect hosts (Kariu et al. 2006). In mice, recombinant PfCelTOS in Montanide ISA 720 elicited potent humoral and cellular immune responses as well as sterile protection against heterologous challenge with Plasmodium berghei sporozoites (Bergmann-Leitner et al. 2010). This was corroborated using an alternative recombinant PfCelTOS in glucopyranosyl lipid adjuvant-stable emulsion (GLA-SE) or glucopyranosyl lipid adjuvant-liposome-QS21 (GLA-LSQ) adjuvant (Espinosa et al. 2017). In addition, monoclonal antibodies raised against $P f C e l-$ TOS inhibited oocyst development of $P$. falciparum, and P. berghei expressing PfCelTOS, in Anopheles gambiae mosquitoes. Notwithstanding these findings, CelTOS is an attractive target for immunization as it is conserved across plasmodial species (Kariu et al. 2006).

We developed a recombinant protein vaccine candidate based on PfCelTOS in E. coli. On characterization of the protein product, we observed that the PfCelTOS reversibly refolds after thermal denaturation; this property may be valuable for cold-chain storage or use in temperate climates. To address the impact of codon harmonization on primary, secondary, and tertiary structure, recombinant protein was produced using the native gene sequence (N-PfCelTOS) and compared with protein produced from the codon-harmonized sequence (CH-PfCelTOS). We utilized circular dichroism (CD), mass spectrometry (MS), and size-exclusion chromatography to characterize the two proteins and identified differences in mass and heterogeneity. A deeper analysis by liquid chromatography-tandem mass spectrometry (LC-MS/MS) revealed amino acid misincorporations in both proteins. Interestingly, despite these changes in amino acid sequence, both proteins reversibly refolded after heat denaturation despite detectable changes in primary and secondary structure. The potential impact of these changes as immunogens also was evaluated in vivo in Balb/cJ mice. Antibody fine specificities were assessed against full length PfCelTOS or subunit fragments reflecting the $\mathrm{N}$-terminus or $\mathrm{C}$-terminus to better define any differences. $\mathrm{CH}$-PfCelTOS induced significantly higher antibody levels compared with N-PfCelTOS; however, no significant differences in cellular responses were detected.

\section{Materials and methods \\ Sequences}

Proteins were produced in E. coli using either the native or codon harmonized DNA sequences. Gene inserts were synthesized and cloned into the $\mathrm{pET}(\mathrm{K})$ expression plasmids (DNA 2.0, currently ATUM, Newark, CA) and transformed into B834 (DE3) E. coli. Both native and codon harmonized sequences (GenBank Accession \# KH833194) encoded the same 174 amino acids and included a 16 amino acid linker containing an N-terminal 6-Histidine tag (Bergmann-Leitner et al. 2010). A Histidine tag-free PfCelTOS was expressed in E. coli as above, and similar to the $\mathrm{N}$ - and $\mathrm{CH}$-PfCelTOS proteins were expressed without the native PfCelTOS signal sequence. Primer pairs used to generate the Histidine tag free $P f C$ CelTOS clone from the $\mathrm{CH}$-PfCelTOS (N-terminal Histidine tagged protein) used $\mathrm{Xba \textrm {I }}$ and $\mathrm{KpnI}$ to replace the nucleotide sequences using $X b a \mathrm{I}-\mathrm{NdeI} K p n \mathrm{I} 5^{\prime}$-CTA GAAATAATTTTGTTTAACTTTAAGAAGGAGATA TACATATGGGTAC- $3^{\prime}$ and KpnI NdeI-XbaI 5'-CCA TATGTATATCTCCTTCTTAAAGTTAAACAAAAT TATTT-3' annealed primers. His-tag free PfCelTOS 
was 161 amino acids long, including two non-native amino acid residues introduced by cloning, GT. All full length clones were initiated at amino acids F R G... and contained 158 of PfCelTOS amino acids. An N-terminal protein fragment of $P f C e l T O S$ (natural residues numbering \#25-149) and C-terminal fragment of PfCelTOS (residues \#85-182) were expressed under identical conditions as for the full length $P f C$ elTOS and used as a reagents to assess fine specificities of immune responses.

\section{Expression of N-PfCelTOS and CH-PfCelTOS}

To investigate the effect of codon usage on PfCelTOS expression, cultures were grown in the presence of $40 \mu \mathrm{g} / \mathrm{mL}$ kanamycin (Sigma Aldrich, St. Louis, MO) in $1 \mathrm{~L}$ Difco Terrific Broth (BD Biosciences, San Jose, CA) at $30{ }^{\circ} \mathrm{C}$. Cells were induced by adding $0.1 \mathrm{mM}$ isopropyl $\beta$-D-1-thiogalactopyranoside (IPTG) (Sigma Aldrich) at an $\mathrm{OD}_{600} \sim 0.8-1.0$ for protein induction. Cell samples were collected every hour from the time of induction for 3 consecutive hours for analysis by SDS-PAGE (Invitrogen, Waltham, MA). Subunit fragments representing the $\mathrm{N}$-terminus and $\mathrm{C}$-terminus of PfCelTOS essentially were expressed using the same conditions as for full length PfCelTOS.

\section{Solubility of N-PfCelTOS and CH-PfCelTOS}

Cell paste $(3 \mathrm{~g})$ was homogenized (Ultra Turrax T-25, Cole Palmer, Vernon Hills, IL) in $60 \mathrm{~mL}$ of lysis buffer (PBS; pH 7.4) (Quality Biological, Gaithersburg, MD). Cells were subjected to microfluidization (Microfluidics Corporation, Model M-110 Y, Westwood, MA) and the cell lysates were divided equally into four parts (by volume). Each part was treated with $1 \%$ Tween $80(\mathrm{v} / \mathrm{v})$ (Fisher Scientific), 1\% deoxycholate (v/v) (Fisher Scientific, Rockville, MD) or 1\% sarkosyl (v/v) (Sigma-Aldrich, St. Louis, MO) and one part was left "untreated". Detergent extractions were carried out at $30{ }^{\circ} \mathrm{C}$ for $1 \mathrm{~h}$ in an incubator shaker at $\sim 50 \mathrm{rpm}$. Treated lysates were centrifuged at $12,000 \mathrm{rpm}$ for $1 \mathrm{~h}$ at $4{ }^{\circ} \mathrm{C}$ to separate soluble supernatants and insoluble pellet fractions. Samples from each fraction were prepared for SDS-PAGE/Coomassie Blue staining (Bio-Rad, Philadelphia, PA).

\section{Purification of N-PfCelTOS and CH-PfCelTOS}

Cell paste $(4 \mathrm{~g})$ for both clones (N-PfCelTOS and $\mathrm{CH}$ PfCelTOS) was homogenized in $60 \mathrm{~mL}$ of lysis buffer (10 $\mathrm{mM} \mathrm{NaH} \mathrm{PO}_{4}, 50 \mathrm{mM} \mathrm{NaCl}, 10 \mathrm{mM}$ imidazole, $2 \mathrm{mM} \mathrm{MgCl} 2, \mathrm{pH}$ 7.4) and lysed by microfluidization. To adjust the final salt concentration, $5 \mathrm{M} \mathrm{NaCl}$ was added to each lysate. Protein was extracted at $30{ }^{\circ} \mathrm{C}$ for $30 \mathrm{~min}$ by addition of $1 \%(\mathrm{v} / \mathrm{v})$ sarkosyl. Extracted lysates were centrifuged at $12,000 \mathrm{rpm}$ at $4{ }^{\circ} \mathrm{C}$ for $1 \mathrm{~h}$ to isolate soluble proteins.
Purification for both proteins was carried out simultaneously under identical conditions. The lysates were passed through $3.5 \mathrm{~mL}$ Nickel-nitriletriacetic acid (Qiagen, Germantown, MD) gravity columns. Columns were washed with 20 column volumes $(\mathrm{CV})$ of equilibrium buffer $\left(10 \mathrm{mM} \mathrm{NaH}_{2} \mathrm{PO}_{4}, 1 \mathrm{M} \mathrm{NaCl}, 0.3 \%\right.$ sarkosyl, $10 \mathrm{mM}$ imidazole, $\mathrm{pH} 7.4$ ), $15 \mathrm{CV}$ of wash buffer 1 (10 $\mathrm{mM} \mathrm{NaH}_{2} \mathrm{PO}_{4}, 500 \mathrm{mM} \mathrm{NaCl}, 0.3 \%$ sarkosyl, $\mathrm{pH}$ 6.5), $10 \mathrm{CV}$ of wash buffer $2\left(10 \mathrm{mM} \mathrm{NaH}_{2} \mathrm{PO}_{4}, 200 \mathrm{mM}\right.$ $\mathrm{NaCl}, \mathrm{pH} 6.5)$, and $10 \mathrm{CV}$ of wash buffer $3(10 \mathrm{mM}$ $\mathrm{NaH}_{2} \mathrm{PO}_{4}, 50 \mathrm{mM} \mathrm{NaCl}, 100 \mathrm{mM}$ imidazole, $\mathrm{pH}$ 6.2). Proteins were eluted with elution buffer, $(10 \mathrm{mM}$ $\mathrm{NaH}_{2} \mathrm{PO}_{4}, 50 \mathrm{mM} \mathrm{NaCl}, 300 \mathrm{mM}$ imidazole, $\mathrm{pH}$ 6.2) and dialyzed against phosphate buffer saline (PBS) (pH 7.4) at $4{ }^{\circ} \mathrm{C}$. Dialyzed proteins were polished through $3.5 \mathrm{~mL}$ of Q-Sepharose (GE Healthcare, Chicago, IL) and the final product dialyzed into PBS (pH 7.4). The $\mathrm{N}$-terminal protein fragment of PfCelTOS (residue \#25149) and C-terminal fragment of PfCelTOS (residue \#85-182) essentially were purified using identical chromatographic conditions as the full length PfCelTOS.

For the purification of histidine tag-free $\mathrm{CH}$-PfCelTOS, lysate was passed through a $2 \mathrm{~mL}$ Q-Sepharose column followed by $30 \mathrm{CV}$ of equilibration wash $(10 \mathrm{mM}$ $\mathrm{NaH}_{2} \mathrm{PO}_{4}, 50 \mathrm{mM} \mathrm{NaCl}, 0.2 \%$ Tween 80; $\mathrm{pH} 7$ ). The column was washed with $40 \mathrm{CV}$ of wash 1 buffer $(10 \mathrm{mM}$ $\mathrm{NaH}_{2} \mathrm{PO}_{4}, 260 \mathrm{mM} \mathrm{NaCl}, 0.2 \%$ Tween 80; $\mathrm{pH}$ 7) followed by elution with $10 \mathrm{CV}$ of elution buffer $\left(10 \mathrm{mM} \mathrm{NaH}_{2} \mathrm{PO}_{4}\right.$, $500 \mathrm{mM} \mathrm{NaCl}, 0.2 \%$ Tween 80; pH 7). Eluted fraction was dialyzed in Q-Sepharose equilibration buffer $(10 \mathrm{mM}$ $\mathrm{NaH}_{2} \mathrm{PO}_{4}, 50 \mathrm{mM} \mathrm{NaCl}, 0.6 \%$ beta octyl-glucopyranoside) and was loaded onto a $2 \mathrm{~mL}$ Q-Sepharose column. Protein was eluted using a linear salt gradient formed between the equilibration buffer and elution buffer $\left(10 \mathrm{mM} \mathrm{NaH} \mathrm{PO}_{4}, 500 \mathrm{mM} \mathrm{NaCl}, 0.6 \%\right.$ beta $\beta$-octylglucopyranoside). The eluted fraction was dialyzed into HIC equilibration buffer, $\left(50 \mathrm{mM} \mathrm{NaH}_{2} \mathrm{PO}_{4}, 1 \mathrm{M}\right.$ ammonium sulfate, $\mathrm{pH} 7.4$ ), and loaded onto a $1 \mathrm{~mL}$ Phenyl Sepharose (GE Healthcare, Chicago, IL) and eluted using a linear gradient formed between the equilibration buffer and elution buffer $\left(50 \mathrm{mM} \mathrm{NaH}{ }_{2} \mathrm{PO} 4,50 \mathrm{mM}\right.$ ammonium sulfate, $\mathrm{pH}$ 7.4). The final elution fraction was dialyzed in $1 \times$ PBS, pH 7.4.

\section{SDS-PAGE/Coomassie Blue and immunoblotting}

Purified proteins were separated on 4-20\% gradient Tris-glycine SDS-PAGE gels and stained with Coomassie Blue R-250. For western blotting, proteins were transferred to $0.2 \mu \mathrm{m}$ nitrocellulose membranes (Invitrogen, Waltham, MA) and blocked in PBS (pH 7.4), 0.1\% Tween 20 (PBS-T) with $0.5 \%$ non-fat dry milk for $30 \mathrm{~min}$ at room temperature (RT). Western blots were probed with PfCelTOS-specific mouse mAbs 3D11.D4, 4H9.C3 and 
3C3.B3 and anti-Histidine mouse mAb (at 1:3000 each) (Takara Bio, Mountain View, CA) for $1 \mathrm{~h}$. After washing with PBS-T, blots were probed with alkaline phosphatase (AP)-conjugated anti-mouse IgG (1:5000) (Southern Biotech, Birmingham, AL). Blots were washed with PBS-T and developed for $10 \mathrm{~min}$ at RT with 4-nitro-blue tetrazolium chloride (NBT) and 5-bromo-4-chloro-3-indolyl phosphate (BCIP) (Roche, Branchburg, NJ) in $0.1 \mathrm{M}$ sodium chloride, $0.005 \mathrm{M}$ magnesium chloride and $0.1 \mathrm{M}$ Tris- $\mathrm{HCl} \mathrm{pH} 9$.

\section{Stability at different temperatures}

Purified N-PfCelTOS and CH-PfCelTOS were subjected to stability analysis at different temperatures. A $1 \mu \mathrm{g} / 10 \mu \mathrm{L}$ aliquot of each protein was incubated at either $37^{\circ} \mathrm{C}$ or $65^{\circ} \mathrm{C}$ for 1,4 and $24 \mathrm{~h}$. Samples were analyzed by SDS-PAGE/Coomassie Blue staining and western blotting.

\section{Membrane lipid strip assay}

Membrane lipid strips (Echelon Biosciences Inc., Salt Lake City, UT) were blocked in blocking buffer ( $\mathrm{pH}$ 7.2) $1 \times$ PBS, $0.1 \%$ Tween $20,3 \%$ bovine serum albumin (BSA) for $1 \mathrm{~h}$. The strips were probed with $2 \mu \mathrm{g} / \mathrm{mL}$ of N- and $\mathrm{CH}$-PfCelTOS for $1 \mathrm{~h}$. The proteins were pre-treated at either $37^{\circ} \mathrm{C}$ or $65{ }^{\circ} \mathrm{C}$ for 1,4 and $24 \mathrm{~h}$. The strips were washed three times with $5 \mathrm{~mL}$ of wash buffer $(1 \times$ PBS; $0.1 \%$ Tween 20 ) at 5 min intervals and then probed with $P f C e l T O S$-specific rabbit polyclonal serum diluted in blocking buffer (1:5000) for $1 \mathrm{~h}$ as the primary antibody and anti-mouse HRP conjugate (1:5000) (KPL, Gaithersburg, MD) as the secondary antibody. The strips were developed with Pierce ECL Western Blotting detection kit (Thermo Scientific, Rockford, IL) for $1 \mathrm{~min}$ and imaged using VersaDoc (Bio-rad, Hercules, CA). Temperature-untreated proteins (T0) were used as the binding controls for the membrane lipid strip assay.

\section{Circular dichroism spectroscopy}

Thermal denaturation was monitored $\left(2{ }^{\circ} \mathrm{C}\right.$ per minute) from 20 to $95^{\circ} \mathrm{C}$ using a Jasco 810 circular dichroism spectropolarimeter (Jasco Inc., Japan) fitted with a Peltier temperature control unit. The melting temperature was determined from a four-parameter fit of the ellipticity at $220 \mathrm{~nm}$. A protein concentration of $13 \mu \mathrm{M}(\mathrm{N}-\mathrm{PfCelTOS})$ and $10 \mu \mathrm{M}(\mathrm{CH}-$ PfCelTOS) and a $1 \mathrm{~mm}$ cuvette was used for CD analysis. Machine units were converted to molar ellipticity to account for differences in protein concentrations.

\section{Mass spectrometry and peptide analysis}

Proteins in $200 \mathrm{mM}$ ammonium bicarbonate were directly injected into a triple-TOF 5600 high resolution mass spectrometer (Sciex, Foster City, CA), full protein TOF spectra was acquired using Analyst TF software (Version 1.7, Sciex, Foster City, CA). Spectra were analyzed and overlaid using Peakview software (Sciex, Foster City, CA). Molecular weights were calculated from spectra using a BioToolKit application for Peakview software. Calculated $\mathrm{MW}=19.027 .03 \mathrm{~g} / \mathrm{mol}, \mathrm{pI}=5.15$, and the $\varepsilon=9970 \mathrm{M}^{-1} \mathrm{~cm}^{-1}$ for each protein, N-PfCelTOS and CH-PfCelTOS.

\section{LC-MS/MS}

\section{Trypsin digest/peptide extraction}

Proteins were run on 4-20\% Tris-glycine Invitrogen gels. Protein bands were cut from the gel and placed in individual $1.5 \mu \mathrm{L}$ tubes with $300 \mu \mathrm{L} 50 \%$ acetonitrile (ACN) in $25 \mathrm{mM}$ ammonium bicarbonate until fully destained followed by alkylation in $30 \mu \mathrm{L} 50 \mathrm{mM}$ iodoacetamide for $30 \mathrm{~min}$ at RT. Bands were washed with $500 \mu \mathrm{L}$ of $100 \mathrm{mM}$ ammonium bicarbonate for $10 \mathrm{~min}$ and dehydrated in $600 \mu \mathrm{L} 100 \% \mathrm{ACN}$ followed by drying for $3 \mathrm{~min}$ in a SpeedVac. Gel bands were treated with $8 \mu \mathrm{L}$ of $1 \mu \mathrm{g} / \mu \mathrm{L}$ trypsin and $292 \mu \mathrm{L}$ of $50 \mathrm{mM}$ ammonium bicarbonate. Samples were incubated at $37^{\circ} \mathrm{C}$ for $15-18 \mathrm{~h}$, at $450 \mathrm{rpm}$. Reactions were stopped by addition of $2 \mu \mathrm{L}$ of $5 \%$ formic acid followed by addition of $100 \mu \mathrm{L}$ HPLC-grade water. Samples were allowed to incubate at RT for $10 \mathrm{~min}$ followed by centrifugation for $5 \mathrm{~min}$ at 13,000 rpm. Supernatant was aliquoted in labeled tubes containing extraction solution ( $5 \%$ of $50 \% \mathrm{ACN}, 5 \%$ formic acid). Peptides were extracted by adding $400 \mu \mathrm{L}$ of extraction solution, vortexing and allowing to sit for $15 \mathrm{~min}$ followed by centrifuging for $5 \mathrm{~min}$; extraction was repeated three times.

\section{Solid phase extraction}

Samples were desalted using OASIS HLB 1 cc $(30 \mathrm{mg})$ reversed phase cartridges (waters). Columns were activated with $1000 \mu \mathrm{L}$ of $0.1 \%$ trifluoroacetic acid (TFA), $80 \%$ ACN twice. Columns were washed with $1000 \mu \mathrm{L}$ of $0.1 \%$ TFA, $5 \%$ ACN twice. Samples were collected in $1.5 \mathrm{~mL}$ lo-bind tubes. $1000 \mu \mathrm{L}$ of sample was added to each column. Peptides were eluted with $1000 \mu \mathrm{L}$ of $0.1 \%$ TFA, $80 \%$ ACN.

\section{LC-MS}

Samples were reconstituted with $10 \mu \mathrm{L} ; 0.1 \%$ formic acid and analyzed on Ultimate 3000 RSLCnano (Thermo Fisher) system in conjunction with Orbitrap Lumos Fusion Mass Spectrometer (Thermo Fisher). 


\section{Size-exclusion chromatography}

PBS and the gel-filtration column calibration standards were purchased from Sigma. PD-10 and Superdex G-200 columns were purchased from G.E. Healthcare. A Superdex G-200 column was equilibrated with PBS, pH 7.4. The column was first calibrated using three protein standards and a $0.5 \mathrm{~mL}$ loading loop $\left(0.5 \mathrm{~mL} / \mathrm{min}, 4{ }^{\circ} \mathrm{C}\right)$. A calibration curve was made by plotting the calculated MW vs. the elution volume corresponding to the peak max. The data was fit to a single exponential decay equation using Grafit 5.0.13 (Erithacus Software Limited). Each protein sample was run in the same fashion. Three proteins were loaded: (1) N-PfCelTOS; (2) CH-PfCelTOS; (3) tag-free CH-PfCelTOS.

\section{$\mathrm{N}$-PfCelTOS and CH-PfCelTOS mouse immunogenicity}

Six to seven week-old female Balb/cJ mice (The Jackson Laboratories, Sacramento, CA) were purchased and housed under pathogen-free conditions. Ten mice per group were immunized three times on a 3 week interval by the intramuscular route in the thigh muscle with $10 \mu \mathrm{g}$ N-PfCelTOS/Montanide ISA-720 (Seppic Inc. New Jersey, NY) or $10 \mu \mathrm{g}$ CH-PfCelTOS/Montanide ISA720 in $100 \mu \mathrm{L} ; 50 \mu \mathrm{L}$ per side. Blood samples were collected before every immunization for evaluating humoral responses. Two weeks after the third immunization splenocytes were collected for evaluating cellular responses. An adjuvant control group, mice vaccinated with ISA 720 were shared with a concurrent study.

\section{ELISA}

Blood samples were collected from lateral tail veins prior to every immunization. PfCelTOS-specific antibodies were analyzed by enzyme-linked immunosorbent assay (ELISA). Briefly, 2HB Immulon plates (Thermo Scientific, Rochester, NY) were coated with $100 \mu \mathrm{L} /$ well of codonharmonized of each $25 \mathrm{ng}$ PfCelTOS, $15 \mathrm{ng} \mathrm{N}$-terminal PfCelTOS or $15 \mathrm{ng}$ C-terminal PfCelTOS in PBS, pH7.4 (Quality Biological, Gaithersburg, MD) and incubated overnight at $4{ }^{\circ} \mathrm{C}$ in a humidified chamber. After blocking with PBS, $1 \%$ BSA at $22{ }^{\circ} \mathrm{C}$ (VWR, Chicago, IL) for $1 \mathrm{~h}$, individual samples prepared at single dilutions were added to the plate. Antibody concentration was determined by establishing a standard curve (run in parallel with each assay) with purified mouse IgG. For each serum tested, we determined a concentration that was within the linear portion of the reaction curve and used this dilution to extrapolate the actual antibody concentration in the assay wells. A mouse-IgG (Invitrogen, Rochester, NY) standard curve was run in tandem. Plates were incubated for $2 \mathrm{~h}$ at $37^{\circ} \mathrm{C}$ in a humidity chamber followed by addition of $100 \mu \mathrm{L} /$ well AP-conjugated anti-mouse (Promega, Madison, WI). The plates were incubated at $22{ }^{\circ} \mathrm{C}$ in a humidity chamber for $1 \mathrm{~h}$ followed by addition of Blue Phos substrate (Sera Care, KPL, Gaithersburg, MD). Development was arrested by addition of $2 \times$ AP Stop solution (Sera Care, KPL) after $15 \mathrm{~min}$. The plates were read at an absorbance of $630 \mathrm{~nm}$ on SpectraMax M2 (Molecular Devices, Downingtown, PA). The concentration of PfCelTOS-specific (full-length, $\mathrm{N}$ or $\mathrm{C}$ terminal) antibodies $(\mu \mathrm{g} / \mathrm{mL})$ was calculated from the linear portion of the mouse-IgG standard curve.

\section{ELISpot}

Cellular responses were evaluated using IFN- $\gamma$ and IL-4 enzyme-linked immunospot assays (ELISpot). Spleens were harvested under sterile conditions 2 weeks postthird immunization and splenocytes were isolated. The splenocytes were suspended in $90 \%$ dimethyl sulfoxide (DMSO, Sigma Aldrich, St. Louis, MO); 10\% fetal bovine serum (FBS, Gibco, Rockville, MD) and stored under liquid nitrogen until testing. Multiscreen plates were coated with IFN- $\gamma$ and IL-4 capture antibodies (ELISpot, R\&D Systems, Minneapolis, MN) in sterile PBS, pH 7.4 (Quality Biological, Gaithersburg, MD) according to the manufacturer's instructions and incubated overnight at $4{ }^{\circ} \mathrm{C}$ in a humidified chamber. The plates were washed with DMEM (Quality Biological, Gaithersburg, MD) followed by blocking with complete media containing DMEM; $10 \%$ FBS; $2 \mathrm{mM}$ L-glutamine, 58,000 units penicillin/58,000 $\mu \mathrm{g}$ streptomycin, $10 \mathrm{mM}$ HEPES; MEM NEAA, $1 \mathrm{mM}$ sodium pyruvate, 2-mercaptoethanol. Plates were coated with splenocytes from individual samples at a concentration of $2 \times 10^{5}$ cells per well. Cells were stimulated with $10 \mu \mathrm{g} / \mathrm{mL}$ PfCelTOS, $6 \mu \mathrm{g} / \mathrm{mL}$ N-term PfCelTOS, $6 \mu \mathrm{g} /$ $\mathrm{mL}$ C-term PfCelTOS and $1 \mu \mathrm{g} / \mathrm{mL}$ PfCelTOS 15-mer peptide pool for $48 \mathrm{~h}$. Secreted cytokines were detected according to the manufacturer's instructions. Spots were counted using the ELISpot reader (Autoimmun Diagnostika, Straßberg, Germany).

\section{Statistical analysis}

Statistical significance of serological and cellular responses where $\mathrm{p}<0.05$ is considered significant, were evaluated using parametric two-tailed, unpaired T-tests and multiple T-tests, respectively (GraphPad Prism, v 6.07, San Diego, CA). For multiple T-tests, statistical significance was determined using the Holm-Sidak method.

\section{Results}

\section{Features of the expressed proteins}

Previously, we observed a significant increase in the expression of $\mathrm{MSP}_{42}-\mathrm{FVO}$ proteins from codon harmonized sequences (Khan et al. 2012). Protein expressed from either a native or a codon harmonized gene 
sequence of PfCelTOS expressed well in E. coli (data not shown). However, the average yield using an identical purification process for N-PfCelTOS and CH-PfCelTOS was 1.35 and $2.57 \mathrm{mg} / \mathrm{g}$ of wet cell paste, respectively, approximately twofold higher than for the $\mathrm{CH}$ sequence. Protein solubility is an important property of recombinant proteins and is dependent on the $\mathrm{pH}$ and $\mathrm{pI}$ of a protein, ionic strength, temperature, the presence of various solvent additives, and the amino acids on the protein surface. Based on amino acid sequence, PfCelTOS is predicted to be highly soluble. PRO-Sol analysis predicted a scaled solubility value of $0.864(\mathrm{pI}=5.21)$ which is higher than the population average of soluble E. coli proteins with a scaled solubility value of 0.45 (Hebditch et al. 2017). Experimentally, both PfCelTOS proteins partitioned into the soluble phase after lysis in phosphate buffered saline (PBS), pH 7.4 under all detergent treatment conditions $(1 \% \mathrm{v} / \mathrm{v}$ each, Tween $80, \beta$-octylglucopyranoside, sarkosyl), as well as in the absence of detergent (data not shown).

To address differences in protein stability, PfCelTOS proteins were incubated at A: $37^{\circ} \mathrm{C}$ and B: $65{ }^{\circ} \mathrm{C}$, for 1, 4 and up to $24 \mathrm{~h}$ (Fig. 1). High molecular weight aggregates were observed for both proteins during the extended incubations at $37{ }^{\circ} \mathrm{C}$ when analyzed by
SDS-PAGE/Western blotting (Fig. 1). Notably, this was not observed for the same proteins stored for $24 \mathrm{~h}$ at $65{ }^{\circ} \mathrm{C}$, a temperature near the mid-point of the thermal denaturation curve. When probed with highly sensitive anti-His antibodies, N-PfCelTOS exhibited a doublet (Fig. 1b). The weak upper band was not detected by the C-terminal PfCelTOS mAb, 3D11.D4 (Fig. 1c), and was present at nominally low levels since this band was not detected by total protein staining (Fig. 1a). These results suggest that an alternative form of the protein with a slightly higher molecular weight was produced from the native sequence. This upper band was not present in the $\mathrm{CH}$-PfCelTOS protein. A band $(\sim 40 \mathrm{kDa})$ detected by western blotting in both protein preparations suggests a dimeric form of the protein that may be more resistant to denaturation. These data suggest a 'stickiness' that allows for some non-covalent stabilization of multimer forms. The detection of this band by both its N-terminal Histidine tag and C-terminal epitope recognizing 3D11.D4 monoclonal antibody verified that it is a form of PfCelTOS and not an E. coli contaminant.

To assess the specific-binding characteristics of the two CelTOS proteins to cell membrane phospholipids, lipid subset spotted-arrays were evaluated. Both proteins bound to phosphatidylinositol $(4,5)$-diphosphate
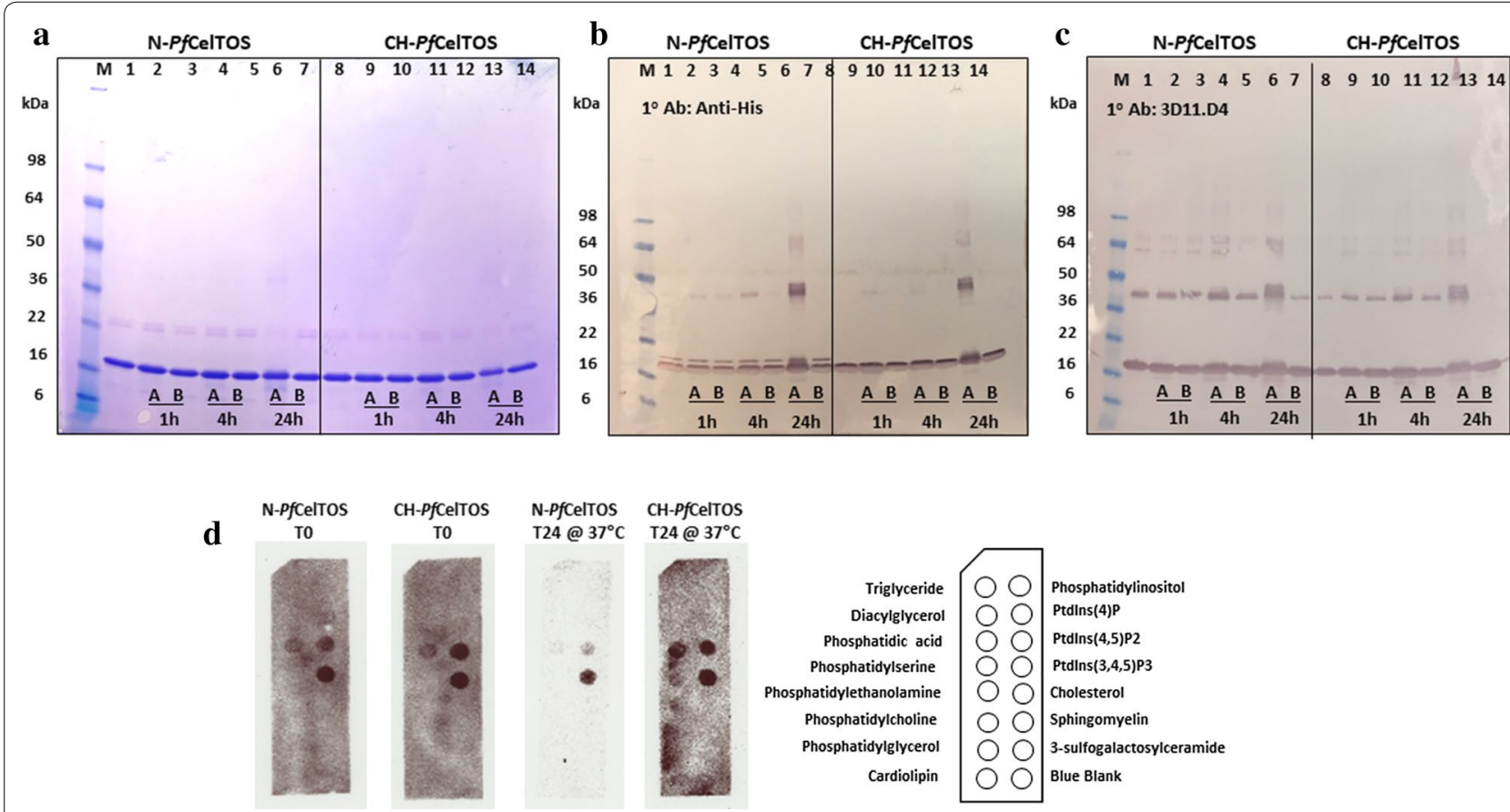

Fig. 1 Stability of $\mathrm{N}$-PfCelTOS and CH-PfCelTOS incubated at $37^{\circ} \mathrm{C}$ and $65^{\circ} \mathrm{C}$. a Coomassie blue total protein staining of $\mathrm{N}$ - and $\mathrm{CH}$-proteins incubated at $\mathrm{A}: 37^{\circ} \mathrm{C}$ and $\mathrm{B}: 65^{\circ} \mathrm{C}$ for 1,4 and up to $24 \mathrm{~h}$. b Western blot analysis using anti-histidine $\mathrm{AAb}$ and $\mathbf{c}$ Western blot analysis using PfCelTOS-C-term specific mAb 3D11.D4. Lane 1 for each gel or blot is the reference PfCelTOS protein, untreated. $\mathbf{d}$ Lipid strip analysis of $\mathrm{N}$ - and $\mathrm{CH}$-PfCelTOS incubated at $37^{\circ} \mathrm{C}$ for up to $24 \mathrm{~h}$. T0 indicates control lipid strips for assessing changes in binding profile of both the proteins 
[PtdIns $(4,5) \mathrm{P} 2]$ and phosphatidylinositol $(3,4,5)$-triphosphate $[\operatorname{PtdIns}(3,4,5) \mathrm{P} 3)]$, phospholipids residing in the plasma membrane, and to phosphatidic acid, which is present within the inner leaflet of the plasma membrane. Incubation at $37^{\circ} \mathrm{C}$ for $24 \mathrm{~h}$ yielded significant loss of binding of N-PfCelTOS to phosphatidic acid and PtdIns $(4,5) \mathrm{P} 2$ compared to $\mathrm{T}=0$ (Fig. $1 \mathrm{~d}$ ) while incubation at $65^{\circ} \mathrm{C}$ for $24 \mathrm{~h}$ completely abrogated lipid binding for both proteins (data not shown). In contrast, $\mathrm{CH}$ PfCelTOS retained the same lipid binding characteristics as at $\mathrm{T}=0$ for $24 \mathrm{~h}$ at $37^{\circ} \mathrm{C}$ and showed no significant functional loss in phospholipid binding. Differences in lipid binding characteristics observed at $37{ }^{\circ} \mathrm{C}$ for $\mathrm{T}=24 \mathrm{~h}$ for $\mathrm{N}$ - and $\mathrm{CH}$-PfCelTOS may be attributed to the differences in their alpha helical content, the types of amino-acid misincorporations, and their propensities to aggregate after unfolding (Fig. 1d). This suggests that the $\mathrm{CH}$-protein is less prone to irreversibly aggregate in solution than the $\mathrm{N}$-protein as its binding site is still accessible to phospholipids at $37^{\circ} \mathrm{C}$. However, at $65^{\circ} \mathrm{C}$, a temperature near the melting temperature of the proteins, no phospholipid binding was observed for either protein at the $24 \mathrm{~h}$ time point (data not shown). These observations were corroborated by the western blot analysis in that at $65{ }^{\circ} \mathrm{C}$ and $24 \mathrm{~h}$, the $\mathrm{N}$-protein showed some level of aggregates, whereas the $\mathrm{CH}$-protein had no dimers or high molecular weight multimeric aggregates (Fig. 1c).

\section{Protein sequence and structure analysis}

Protein secondary structure was examined using CD spectroscopy. The structure of CelTOS from Plasmodium vivax ( $P \nu$ CelTOS) shows that the protein is predominantly helical. CD scans showed that the N-PfCelTOS protein had less alpha helical content than the $\mathrm{CH}$ PfCelTOS. The minima at $222 \mathrm{~nm}$ for the N-PfCelTOS was $82 \%$ of that of $\mathrm{CH}-\mathrm{PfCelTOS}$ and correlates with the alpha helical content of the proteins (Fig. 2a). If the proteins produced from the $\mathrm{N}$ and $\mathrm{CH}$ sequences were identical no difference in alpha helical content would be expected; thus, the result is consistent with amino acid misincorporations and differences in protein primary structure. Nonetheless, despite differences in alpha helical content both proteins reversibly refolded after thermal denaturation (Fig. 2b). In contrast, a recombinant CelTOS derived from the P. berghei (PbCelTOS) sequence showed evidence of irreversible thermal denaturation (Bergmann-Leitner et al. 2011), suggesting that only some variants of the highly conserved CelTOS protein may retain this feature and refold. For $\mathrm{PbCelTOS}$ it is unknown as to how many amino acid misincorporations occur during expression or whether amino acid misincorporations affect its fold.

Mass spectrometry techniques were applied to identify and quantitate the putative amino acid misincorporations in the recombinant CelTOS protein products. $\mathrm{CH}$-PfCelTOS had an average mass of 19,000 Da that compared well with the calculated MW of $19,027 \mathrm{~g} / \mathrm{mol}$. In contrast, the N-PfCelTOS had an average mass of 19,140 Da and a broader mass/charge envelop suggesting greater heterogeneity and higher number of amino acid misincorporations compared with $\mathrm{CH}$-PfCelTOS (Fig. 3). This difference in the distribution of protein masses may account for the differences in secondary structure detected by CD spectroscopy. These findings indicate that the two proteins are indeed structurally different. To resolve the differences in mass detected by MS, we applied high resolution LC-MS/MS. Interestingly,
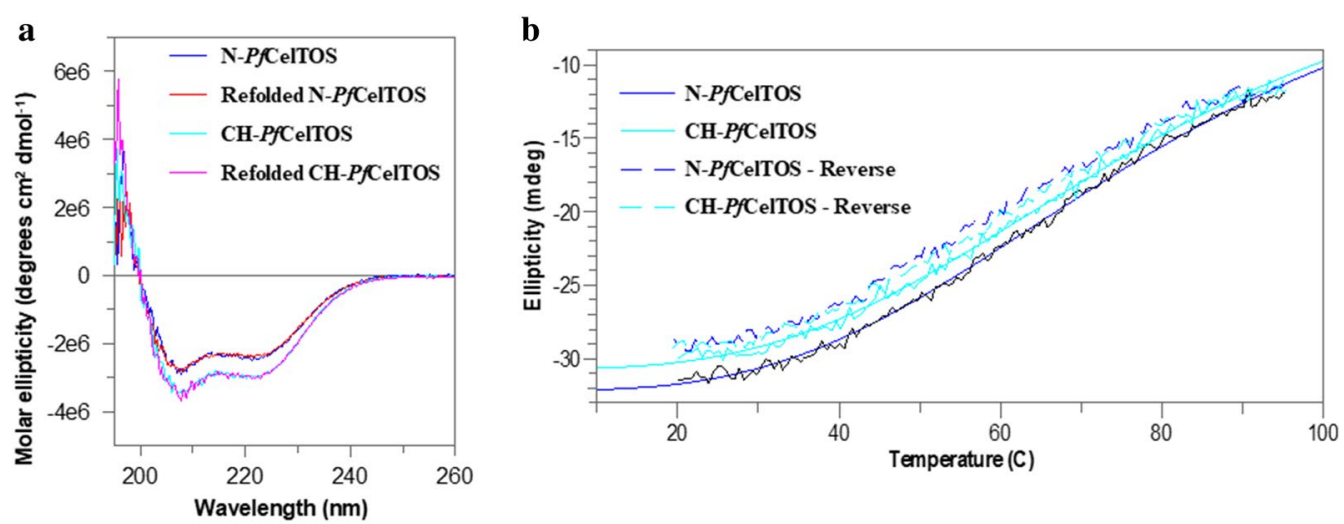

Fig. 2 CH-PfCelTOS contains more helical content than N-PfCelTOS. a CD-spectra of N-PfCelTOS (blue) or CH-PfCelTOS (cyan) proteins; overlaid with the CD spectra of the refolded N-PfCelTOS (red) or refolded CH-PfCelTOS (pink) proteins. b Thermal denaturation curves of the N-PfCelTOS (blue) and CH-PfCelTOS (cyan) and the reversed N-PfCelTOS (dashed blue) and reversed CH-PfCelTOS (dashed cyan). Curves are significantly overlaid 
amino-acid misincorporations were found in both proteins. However, non-synonymous misincorporations seen in the N-PfCelTOS were more varied and numerable compared with CH-PfCelTOS (Table 1). As a general observation, the most common substitutions were hydrophobic to hydrophobic followed by hydrophobic to positively charged amino acids. Hydrophobic to negatively charged amino acid substitutions or substitutions of positively or negatively charged amino acids to neutral ones were rarely observed (Table 2).

To determine if codon usage affected quaternary structure, a calibrated gel-filtration column was used. The column was calibrated using three standard proteins $(66,29$, $12.4 \mathrm{kDa}$ ) and blue dextran to estimate the void volume. The data were fit to a single exponential decay equation $\left(\mathrm{A}=\mathrm{A}_{0}{ }^{*} \mathrm{e}^{-\mathrm{kr}}\right)$ where $\mathrm{v}=$ elution volume of the protein,

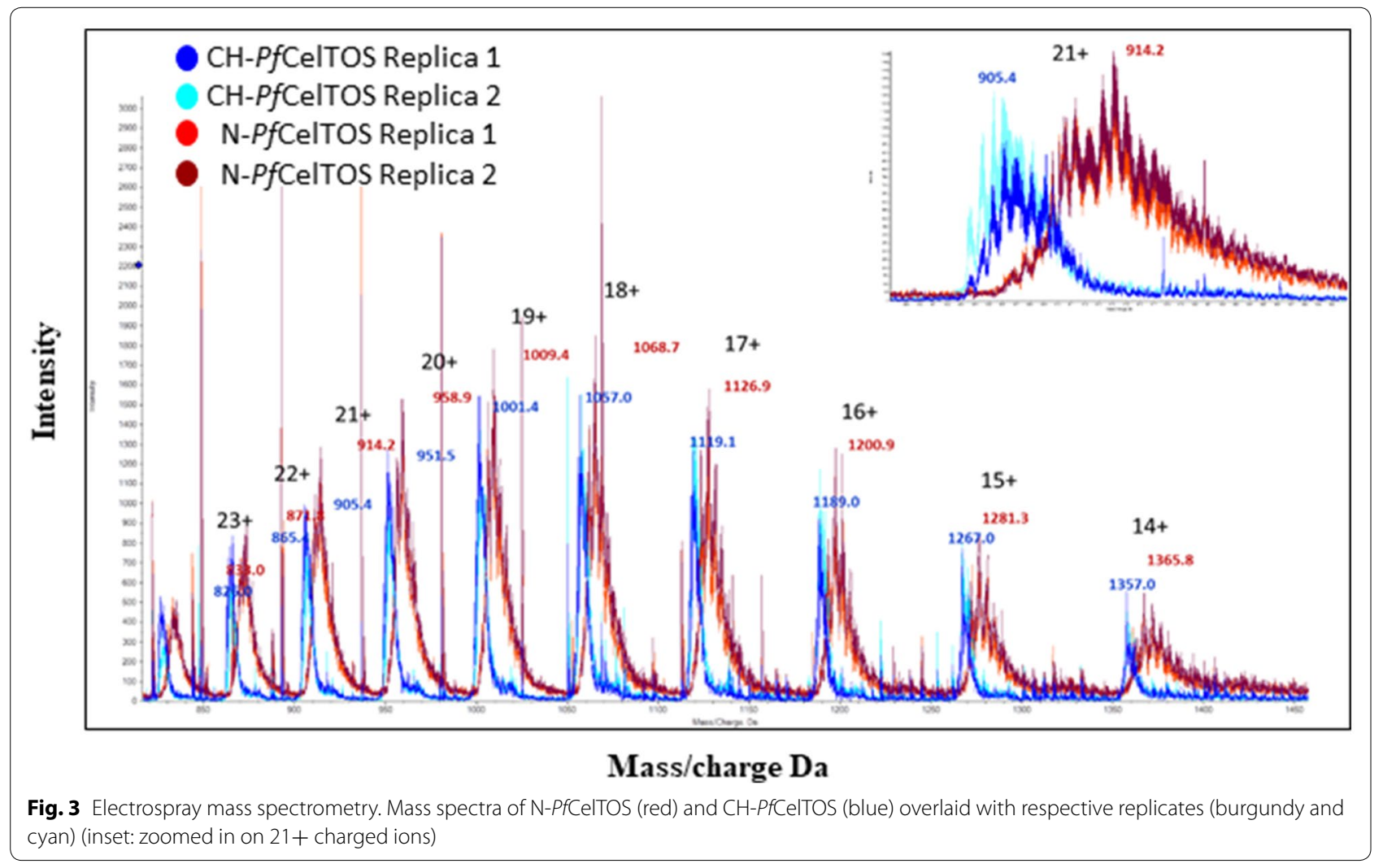

Table 1 Nonsynonymous amino acid substitutions observed by LC-MS/MS for N-PfCelTOS and CH-PfCelTOS

\begin{tabular}{|c|c|c|c|c|c|}
\hline \multicolumn{2}{|c|}{$\begin{array}{l}\mathrm{N}-\mathrm{PfCelTOS} \\
\text { Amino-acid range: \#1 to } 80\end{array}$} & \multicolumn{2}{|c|}{$\begin{array}{l}\text { N-PfCelTOS } \\
\text { Amino-acid range: \#81 to } 182\end{array}$} & \multicolumn{2}{|c|}{$\begin{array}{l}\text { CH-PfCelTOS } \\
\text { Amino-acid range: } \# 1 \text { to } 182\end{array}$} \\
\hline $\begin{array}{l}\text { Amino acid number, } \\
\text { expected acid }\end{array}$ & Substitution(s) & $\begin{array}{l}\text { Amino acid number, } \\
\text { expected acid }\end{array}$ & Substitution(s) & $\begin{array}{l}\text { Amino acid number, } \\
\text { expected acid }\end{array}$ & Substitution(s) \\
\hline $50, S$ & Q & $84, \mathrm{~S}$ & $P$ & 64.1 & $\mathrm{H}$ \\
\hline 64,1 & V & $87, F$ & L & $65, G$ & $\mathrm{~N}$ \\
\hline $65, \mathrm{G}$ & $\mathrm{M} / \mathrm{N} / \mathrm{N}$ & $88, \mathrm{~L}$ & $H / F$ & 73,5 & $\mathrm{~N}$ \\
\hline $68, L$ & $\mathrm{~F}$ & $91, \mathrm{~S}$ & $\mathrm{R}$ & $87, F$ & Y \\
\hline $69, \mathrm{~A}$ & $\mathrm{~N} / \mathrm{H} / \mathrm{Q}$ & $130, V$ & $\mathrm{~F}$ & $88, \mathrm{~L}$ & $\mathrm{H}$ \\
\hline $70, E$ & $\mathrm{Q} / \mathrm{Q}$ & $133, A$ & Q & $144, S$ & $\mathrm{R}$ \\
\hline $71, T$ & $\mathrm{~N} / \mathrm{H} / \mathrm{Q}$ & $135, Y$ & $\mathrm{H} / \mathrm{F}$ & & \\
\hline 72,1 & M & 137,1 & MNN & & \\
\hline $75, E$ & $\mathrm{D}$ & 138,1 & $\mathrm{M} / \mathrm{N} / \mathrm{T} / \mathrm{M} / \mathrm{M}$ & & \\
\hline $83, \mathrm{~N}$ & Y & $139, V$ & $\mathrm{R}$ & & \\
\hline
\end{tabular}


Table 2 Nature of amino-acid substitutions for N-PfCelTOS and CH-PfCelTOS

\begin{tabular}{lll}
\hline Type of substitution & Amino acid number: N-PfCelTOS & Amino acid number: CH-PfCelTOS \\
\hline Hydrophobic to hydrophobic & $64,68,72,87,88,130,135,137,137,137,138,138,138$, & 87 \\
& 138 & 64,88 \\
Hydrophobic to (+) charged & $69,88,135,139$ & None observed \\
Hydrophobic to (-) charged & None observed & None observed \\
Neutral to hydrophobic & 83 & None observed \\
Hydrophobic to neutral & $69,69,133,138$ & None observed \\
$(+)$ charged to neutral & None observed & None observed \\
$(-)$ charged to neutral & 70 & 73 \\
Polar uncharged to polar uncharged & $50,71,71$ & 144 \\
Polar uncharged to (+) charged & $71,88,91$ & None observed \\
Gly/Pro/Ser to hydrophobic & 65 & 65 \\
Gly/Pro/Ser to polar uncharged & 50,50 & None observed \\
Gly/Pro/Ser to Gly/Pro/Ser & 84 &
\end{tabular}

$\mathrm{v}_{\mathrm{o}}=$ void volume, $\mathrm{r}=\mathrm{v} / \mathrm{v}_{\mathrm{o}}$, and $\mathrm{A}=\mathrm{MW}(\mathrm{kDa})$. From a fit to our data, we obtained an $\mathrm{A}_{0}=38,342$ and $\mathrm{k}=3.6245$ and were able to calculate the MW of the PfCelTOS proteins produced using the native or codon-harmonized sequence. For this analysis, we compared three proteins: (1) N-PfCelTOS; (2) CH-PfCelTOS; and (3) a histidine tag-free version of the $\mathrm{CH}$-PfCelTOS, all produced in $E$. coli. The N-PfCelTOS eluted as a $59 \mathrm{kDa}(14.3 \mathrm{~mL})$ protein while the $\mathrm{CH}-\mathrm{PfCelTOS}$ eluted at $70 \mathrm{kDa}(13.9 \mathrm{~mL})$. The histidine tag-free $\mathrm{CH}$-PfCelTOS eluted at $73 \mathrm{kDa}$ $(13.8 \mathrm{~mL})$. Notably, in the histidine tag-free $\mathrm{CH}$-PfCelTOS chromatogram, a second, relatively broad peak eluted between 12 and $13 \mathrm{~mL}$, correlating with a MW range of 104-166 kDa. This peak may correspond to a histidine tag-free hexamer $(104 \mathrm{kDa})$ or octamer $(139 \mathrm{kDa})$. The $\sim 70-73 \mathrm{kDa}$ peaks overlaid well with the $66 \mathrm{kDa}$ standard and may indicate a tetramer $(70-76 \mathrm{kDa})$ depending upon the relative globularity between the multimer and standards (Fig. 4). N-PfCelTOS eluted near where a trimer was expected $(57 \mathrm{kDa})$. Notably, monomers were not observed in either sample. Interestingly, the quaternary structure of a C-terminal His-tagged $P$. vivax CelTOS ( $P v$ CelTOS) was previously reported to be a homodimer based upon analytical ultracentrifugation data (Jimah et al. 2016). However, three molecules of the protein are found within the asymmetric unit of the crystal, and symmetry-related molecules in the crystal lattice pack as hexamers with no density for the N-terminal residues prior to Ser-46 or for the C-terminal residues beyond Tyr-175 (PDB 5TSZ) ( $P v$ CelTOS amino acids 36-196) suggesting that they are either disordered or absent (i.e., degraded or proteolyzed) (Jimah et al. 2016) (Fig. 5). Thus, other quaternary structures cannot be excluded. Since epitopes can form at interfacial locations in multimeric proteins, we next evaluated immunogenicity in mice.

\section{Immunity in mice}

To evaluate immune responses induced by N-PfCelTOS and $\mathrm{CH}-\mathrm{PfCelTOS}$, inbred $\mathrm{Balb} / \mathrm{cJ}$ mice were immunized either with $10 \mu \mathrm{g}$ of $\mathrm{N}$-PfCelTOS or $\mathrm{CH}$-PfCelTOS in Montanide ISA 720 ( $n=10$ /group). Antibody concentrations were determined using a standard ELISA. Serum antibodies were tested against full-length $\mathrm{CH}$-PfCelTOS, $\mathrm{N}$-terminal CH-PfCelTOS and C-terminal CH-PfCelTOS recombinant proteins to assess antibody fine specificities. Both N-PfCelTOS and CH-PfCelTOS immunogens induced robust antibody responses after three immunizations. Antibodies to the full-length and the C-terminal portion of PfCelTOS were detected in high proportions, and statistically higher for the $\mathrm{CH}$-PfCelTOS immunogen (Unpaired t-test, $\mathrm{p}=0.0214$ and $\mathrm{p}=0.0393$, respectively), while $\mathrm{N}$-terminal PfCelTOS recognition was marginal for both groups (Fig. 6b). For cellular responses, the frequencies of IL- 4 and IFN- $\gamma$-producing splenocytes were measured by ELISpot (Bergmann-Leitner et al. 2010). PfCelTOS-specific IFN- $\gamma$ secreting splenocytes were detected in high numbers, indicating a Th1 skew for both groups (Fig. 6c), with significant ex vivo stimulation using the C-terminal PfCelTOS and PfCelTOS peptide pool compared to the full-length or N-terminal $\mathrm{CH}$ PfCelTOS proteins. Differences in stimulation indices for the shorter C-terminal PfCelTOS protein and the peptide pool compared with the full length PfCelTOS may be partially explained by better processing and improving antigen presentation and T-cell activation. The lack of stimulation with the full length protein for detection of IFN- $\gamma$ secreting splenocytes was nominally unexpected (Bergmann-Leitner et al. 2010) and may reflect the quality of the stimulating antigen following multiple freeze thaw cycles. 


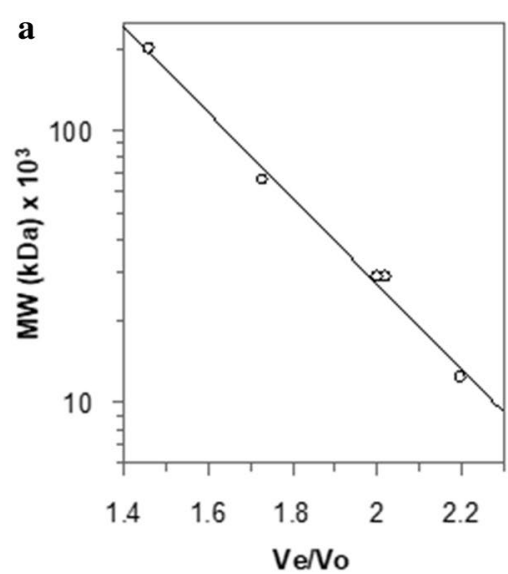

\begin{tabular}{|l|l|l|}
\hline & $\begin{array}{l}\text { Elution } \\
\text { Volume }(\mathbf{m L})\end{array}$ & $\begin{array}{l}\text { MW } \\
(\mathbf{k D a})\end{array}$ \\
\hline Blue Dextran & 7.98 & 2 \\
\hline Bovine Serum Albumin & 13.79 & 66,132 \\
\hline Carbonic Anhydrase & 16.11 & 29 \\
15.99 & 29 \\
\hline Cytochrome-c & 17.53 & 12.4 \\
\hline
\end{tabular}

b
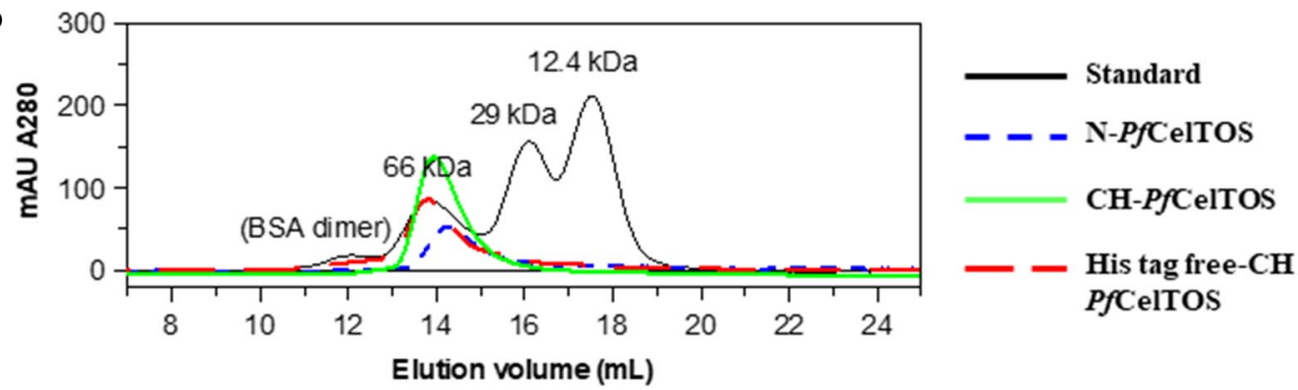

Fig. 4 Size-exclusion chromatography. a Calibration curve using calibration standards: blue dextran (2 kDa), bovine serum albumin (66 kDa), carbonic anhydrase $(29 \mathrm{kDa})$, and cytochrome-c (12.4 kDa). $\mathbf{b} \mathrm{N}$-PfCelTOS is shown in blue dash, CH-PfCelTOS is shown in green and a histidine tag-free version of CH-PfCelTOS is shown in red dash. Calibration standards are overlaid and shown in black

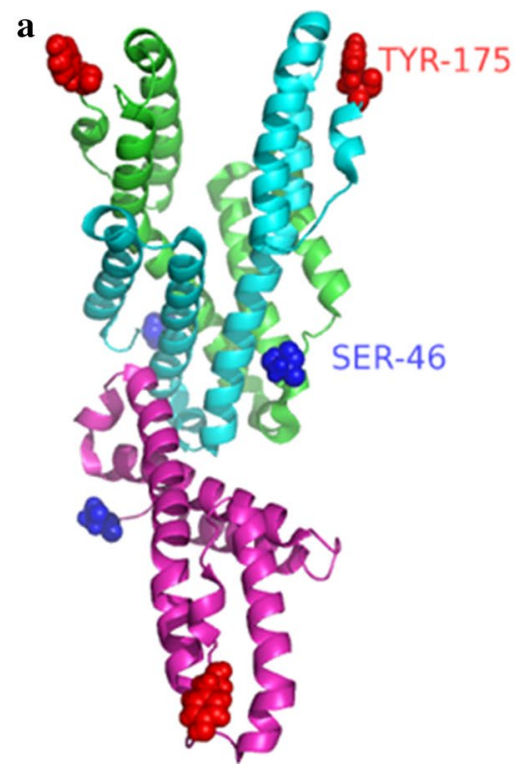

b

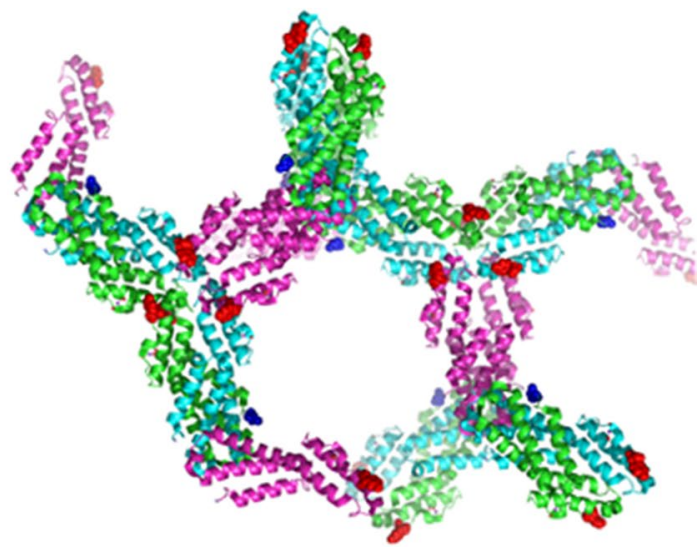

Fig. 5 Structure of CelTOS (PDB 5TSZ) from P. vivax. a Three molecules (green, cyan and magenta) are found in the unit cell. $\mathbf{b}$ Crystal packing is shown. The first and the last ordered residues are Ser-46 (blue spheres) and Tyr-175 (red spheres). The structure is predominantly helical 


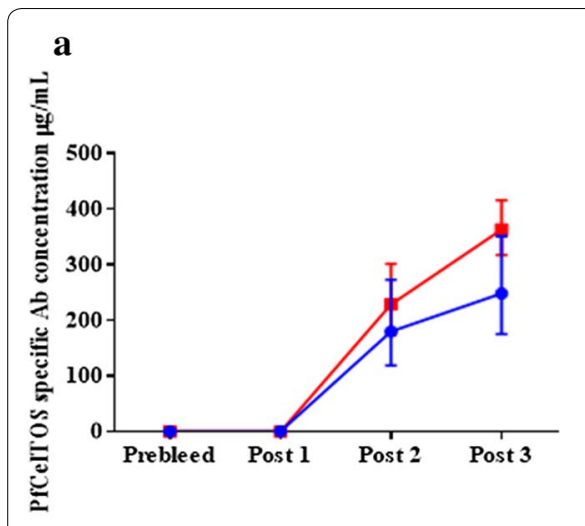

b

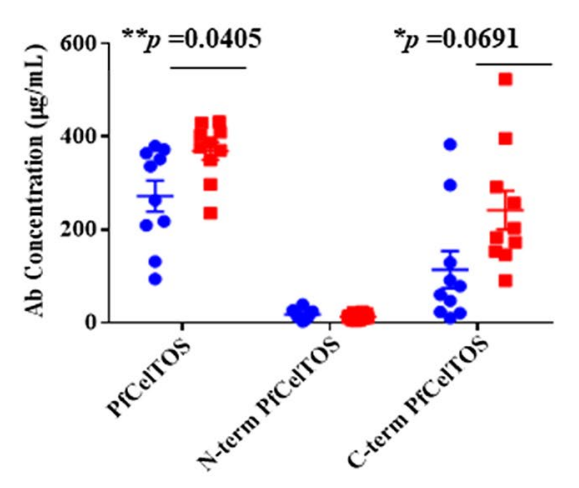

10 ug N-PfCelTOS/ ISA 720

$10 \mathrm{ug}$ CH-PfCelTOS/ISA 720
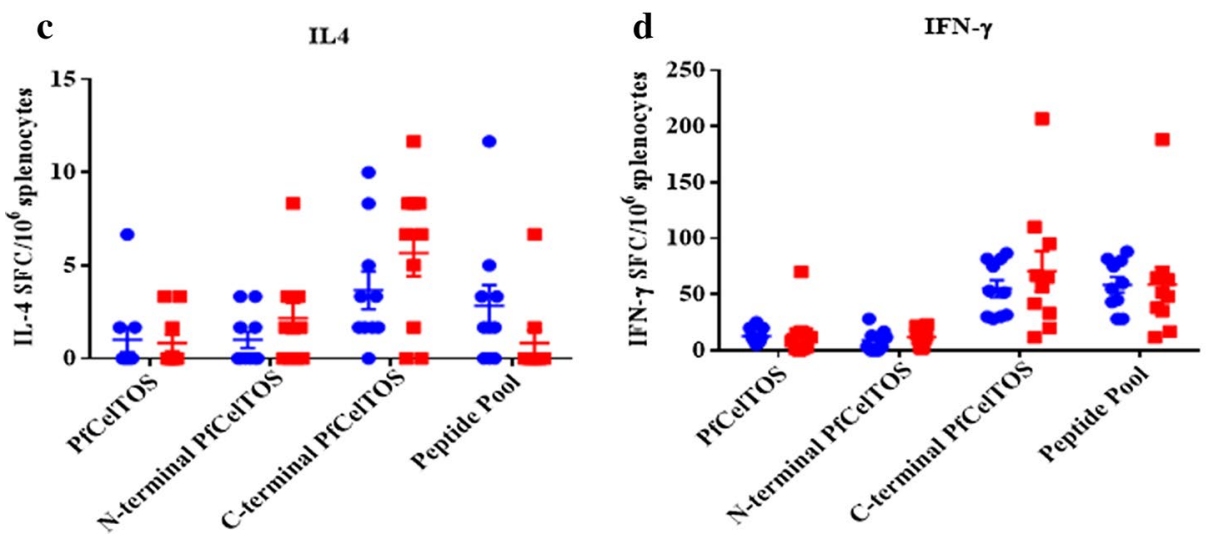

- 10 ug N-PfCelTOS/ ISA 720

- 10 ug CH-PfCelTOS/ISA 720

Fig. $6 \mathrm{~N}$-PfCelTOS and CH-PfCelTOS induce comparable antibody and TH1 biased cellular responses. a Kinetic of PfCelTOS specific antibody responses, reported as antigen specific concentrations $(\mu \mathrm{g} / \mathrm{mL})$. Geometric means and $95 \%$ confidence interval are reported. b Scatter plot of individual mouse responses at 2 weeks post 3rd immunization reported as the mean and standard deviation. Statistical significance of differences in antibody responses induced by N-PfCelTOS and CH-PfCelTOS was determined using Parametric, two tailed, unpaired T-test ${ }^{* *} p=0.0214$, ${ }^{*} \mathrm{p}=0.00393$ against PfCelTOS and C-terminus of PfCelTOS proteins, respectively). Splenocytes from individual mice were tested for secretion of IL-4 and IFN- $\gamma$ cytokines by ELISpot. Data are reported as the mean plus standard error of the mean of cytokine producing cells (spot forming cells (SFC) $/ 10^{6}$ splenocytes) of individual mice (c) IL-4 and (d) IFN- $\gamma$

\section{Discussion}

Single synonymous codon substitutions within a coding region can significantly alter substrate specificities (Kimchi-Sarfaty et al. 2007) or enzymatic activities (Komar et al. 1999) of proteins demonstrating that even subtle changes can have a significant impact on final protein structure/function. These subtle differences in coding sequence may serve to regulate protein folding kinetics. While we and others have observed that codon substitutions can alter protein expression, primary, secondary, and quaternary structure, the impact of these changes has not been fully assessed for vaccine immunogens. For example, altered peptide ligands have been intentionally used to modulate T-cell responses to immunotoxin therapeutics (Candia et al. 2016; Castelletti and Colombatti
2005). The so-called Hoskins effect (also known as "original antigenic sin") refers to a phenomenon where prior exposure to an antigen can alter immune responses to a second similar antigen and reduce an immune response. Thus, we hypothesized that variability in amino acid sequence could potentially impact immune responses. Here, PfCelTOS was "codon harmonized" to optimize its expression. It was then systematically compared with protein expressed from the native DNA sequence to evaluate the impact of codon usage on the integrity of the final product. Our findings suggest that the two proteins are biophysically different in primary, secondary, and quaternary structure.

In comparing N-PfCelTOS and CH-PfCelTOS, we expected to find differences in expression levels, 
solubility, and yield for the two products as previously observed for $\mathrm{MSP}_{42}$ (Khan et al. 2012). While both proteins expressed well in E. coli and were highly soluble, we found them to be different in mass, homogeneity (number of misincorporation events), and secondary structure. Differences in quaternary structure also were detectable in size exclusion chromatograms. Notably, both PfCelTOS proteins reversibly refolded after thermal denaturation; thus, any differences in secondary structure did not significantly affect reversible refolding.

We found that the codon-harmonized protein mass was more similar to the theoretical molecular weight, compared with the native protein which exhibited a greater mass. The broader distribution of masses in mass spectra suggested that the protein produced from the native DNA sequence was more heterogeneous. An attempt to identify the cause of these differences in mass revealed a significantly higher number of amino acid misincorporations in protein expressed from the native DNA sequence. Although amino acid misincorporation is reported to occur at low levels in E. coli, it is dependent upon many factors including the expression system and cell lines (Bouadloun et al. 1983; Edelmann and Gallant 1977; Ellis and Gallant 1982; Kramer and Farabaugh 2007; Laughrea et al. 1987; Loftfield 1963; Loftfield and Vanderjagt 1972; Manickam et al. 2014; Stansfield et al. 1998; Yu et al. 2009; Zhang et al. 2013). Generally, it is estimated that anywhere between 10 and $50 \%$ of misincorporations affect protein function (Drummond and Wilke 2008, 2009). These sequence variations can cause protein heterogeneity and altered catalytic activity (Kramer and Farabaugh 2007; Stansfield et al. 1998), disrupt ligand and substrate binding and affect protein folding, leading to aggregation (Drummond and Wilke 2008; Lee et al. 2006). In some cases, high levels of sequence variants can cause undesired immune responses (Drummond and Wilke 2008, 2009; Katsara et al. 2008). Interestingly, misincorporation at rarely used codons does not occur more frequently than at commonly used codons, rather misincorporation errors may be context-dependent (Parker 1992). In the current study, we observed a larger number of sequence variations in N-PfCelTOS than in the CH-PfCelTOS. The most common substitutions being hydrophobic to hydrophobic amino acids, and hydrophobic to positively-charged amino acids. Interestingly, hydrophobic to negatively-charged amino acid substitutions and positively-charged to neutral substitutions were not observed. These substitutions likely account for the differences in alpha helical content and suggest that codon usage impacts the misincorporation of amino acids. A factor not extensively discussed is the influence of the Histidine-tag and its location on protein tertiary and quaternary structure, as well as its influence on immunogenicity. A codon-optimized, C-terminal
His-tagged $P \nu$ CelTOS (P. vivax CelTOS) was previously shown to form a homodimer (Jimah et al. 2016); our results indicate that the $\mathrm{N}$-terminal His-tagged or a tagfree, codon harmonized PfCelTOS appears to form multimers larger than a dimer (possibly trimers or tetramers). These predictions of higher order structures are of particular interest with regards to the role of PfCelTOS in host cell traversal. It has been shown that CelTOS binds to phosphatidic acid on the inner leaflet of the cell membrane and functions to disrupt the plasma membrane by assembling a pore on the cytoplasmic-face to enable the exit of parasites from invaded host cells during cell traversal (Jimah et al. 2016). A biologically relevant in vivo phenomenon requiring protein functionality, nominally at an elevated temperature of $37^{\circ} \mathrm{C}$ (Fig. 1d).

Quaternary structure can affect the immunogenicity of subunit vaccines in cases where conformational epitopes are present at protein-protein interfaces. For example, antibodies against viral envelop proteins can bridge adjacent epitopes to prevent conformational changes and can ultimately inhibit entry and egress of enveloped viruses (Fox et al. 2015). With respect to immunogens, the presentation of mixtures of different but related protein sequences such as site-directed mutants can reduce humoral immune responses and can impact the protective efficacy of an immunogen (Candia et al. 2016). These immunosuppressive effects are sequence-dependent as only some peptides bind MHC molecules and T-cell receptors. Here, we did not observe a significant difference in cellular responses; however, antibody levels induced by the $\mathrm{CH}$-PfCelTOS were significantly higher than those induced by N-PfCelTOS. Accurate detection of the effects of low abundance mistranslated proteins and peptides, against a background of wild-type protein, is challenging. Our findings suggest that the impact of these misincorporations on the immunogenicity of these protein products may be relatively low. Nevertheless, the impact of these sequence variants on the final product quality is difficult to estimate. Differences in the loss of phospholipid binding affinity were observed between the N-PfCelTOS and CH-PfCelTOS after the protein was subjected to a $24 \mathrm{~h}$ incubation at $37^{\circ} \mathrm{C}$ suggesting a reduced propensity for the $\mathrm{CH}$-protein to irreversibly aggregate. It should be noted that the recombinant PfCelTOS constructs used here do not have cysteine residues. The $\mathrm{CH}$-protein better retained its ability to bind phospholipids after the $37{ }^{\circ} \mathrm{C} 24 \mathrm{~h}$ incubation, suggesting a level of structural integrity. High molecular weight multimers that withstood SDS-PAGE separation also were observed for both proteins in western blots after $24 \mathrm{~h}$ incubation at $37^{\circ} \mathrm{C}$. After incubation at $65{ }^{\circ} \mathrm{C}$ for $24 \mathrm{~h}$, a temperature near the mid-point of the thermal denaturation curve, fewer dimers and high molecular multimers were observed for the $\mathrm{CH}$ protein in western blots suggesting fewer non-specific 
aggregates. Aggregation and protein precipitation are typically irreversible processes. Thus, these differences in thermostability may affect long-term storage. While heterologous expression in E. coli may be facile and economical, our results show the potential impact of codon usage on the fidelity of protein synthesis and protein homogeneity.

\section{Acknowledgements}

This work was supported by the Military Infectious Disease Research Program (MIDRP). We thank Ms. Katherine Mallory for providing technical assistance on the animal studies and immunological assays. We thank Ms. Alexandra Urman for performing the LC-MS/MS experiments.

\section{Disclaimer}

The interpretations and opinions expressed herein belong to the authors and do not necessarily represent the official views of the U.S. Army, U.S. Navy, U.S. Department of Defense or the U.S. government.

\section{Authors' contributions}

EA, designed experiments, analyzed data, prepared and finalized manuscript versions. PML designed experiments, drafted/edited manuscript versions, performed CD analysis, sizing and structural modeling of CelTOS proteins. NP drafted and revised the manuscript, prepared figures, performed protein expression, purifications, analysis by SDS-PAGE/Western blotting, phospholipid strip binding, animal studies, immunogenicity studies, analyzed data. DL performed MS analysis, reviewed data, and edited manuscript. JK performed LC/MS/MS analysis, reviewed data and edited manuscript. All authors read and approved the final manuscript.

\section{Funding}

This work was funded by the U.S. Military Infectious Disease Research Program (MIDRP).

\section{Availability of data and materials}

Accession number, KH833194 identified the nucleic acid sequence of the $\mathrm{CH}$ PfCelTOS. All materials are available upon request.

\section{Ethics approval and consent to participate}

All applicable international, national, and/or institutional guidelines for the care and use of animals were followed. Research was conducted in an AAALACi accredited facility in compliance with the Animal Welfare Act and other federal statutes and regulations relating to animals and experiments involving animals and adheres to principles stated in the Guide for the Care and Use of Laboratory Animals, NRC Publication, 2011 edition.

\section{Consent for publication}

All authors provide their consent for publication of the manuscript.

\section{Competing interests}

Authors declare no competing interests except for Dr. Evelina Angov who declares a competing interest; she holds an issued US patent on the recombinant PfCelTOS and its use.

\section{Author details}

${ }^{1}$ Malaria Biologics Branch, Walter Reed Army Institute of Research, Silver Spring, MD 20910, USA. ${ }^{2}$ Naval Research Laboratories, 4555 Overlook Ave, Washington, DC 20375, USA. ${ }^{3}$ The Geneva Foundation, 917 Pacific Avenue, Tacoma, WA 98402, USA.

Received: 17 September 2019 Accepted: 1 October 2019 Published online: 19 October 2019

\section{References}

Angov E, Hillier CJ, Kincaid RL, Lyon JA (2008) Heterologous protein expression is enhanced by harmonizing the codon usage frequencies of the target gene with those of the expression host. PLOS ONE 3:e2189
Bergmann-Leitner ES, Mease RM, De La Vega P, Savranskaya T, Polhemus M, Ockenhouse C, Angov E (2010) Immunization with pre-erythrocytic antigen CelTOS from Plasmodium falciparum elicits cross-species protection against heterologous challenge with Plasmodium berghei. PLOS ONE 5:e12294

Bergmann-Leitner ES, Legler PM, Savranskaya T, Ockenhouse CF, Angov E (2011) Cellular and humoral immune effector mechanisms required for sterile protection against sporozoite challenge induced with the novel malaria vaccine candidate CelTOS. Vaccine 29:5940-5949

Bouadloun F, Donner D, Kurland CG (1983) Codon-specific missense errors in vivo. EMBO J 2:1351-1356

Candia M, Kratzer B, PickI WF (2016) On peptides and altered peptide ligands: from origin, mode of action and design to clinical application (immunotherapy). Int Arch Allergy Immunol 170:211-233

Castelletti D, Colombatti M (2005) Peptide analogues of a T-cell epitope of ricin toxin A-chain prevent agonist-mediated human T-cell response. Int Immunol 17:365-372

Darko CA, Angov E, Collins WE, Bergmann-Leitner ES, Girouard AS, Hitt SL, McBride JS, Diggs CL, Holder AA, Long CA, Barnwell JW, Lyon JA (2005) The clinical-grade 42-kilodalton fragment of merozoite surface protein 1 of Plasmodium falciparum strain FVO expressed in Escherichia coli protects Aotus nancymai against challenge with homologous erythrocytic-stage parasites. Infect Immun 73:287-297

Drummond DA, Wilke CO (2008) Mistranslation-induced protein misfolding as a dominant constraint on coding-sequence evolution. Cell 134:341-352

Drummond DA, Wilke CO (2009) The evolutionary consequences of erroneous protein synthesis. Nat Rev Genet 10:715-724

Edelmann P, Gallant J (1977) Mistranslation in E. coli. Cell 10:131-137

Ellis N, Gallant J (1982) An estimate of the global error frequency in translation. Mol Gen Genet 188:169-172

Espinosa DA, Vega-Rodriguez J, Flores-Garcia Y, Noe AR, Munoz C, Coleman R, Bruck T, Haney K, Stevens A, Retallack D, Allen J, Vedvick TS, Fox CB, Reed SG, Howard RF, Salman AM, Janse CJ, Khan SM, Zavala F, Gutierrez GM (2017) The Plasmodium falciparum cell-traversal protein for ookinetes and sporozoites as a candidate for preerythrocytic and transmission-blocking vaccines. Infect Immun. https://doi.org/10.1128/IAl.00498-16

Fox JM, Long F, Edeling MA, Lin H, van Duijl-Richter MKS, Fong RH, Kahle KM, Smit JM, Jin J, Simmons G, Doranz BJ, Crowe JE Jr, Fremont DH, Rossmann MG, Diamond MS (2015) Broadly neutralizing alphavirus antibodies bind an epitope on E2 and inhibit entry and egress. Cell 163:1095-1107

Hebditch M, Carballo-Amador MA, Charonis S, Curtis R, Warwicker J (2017) Protein-Sol: a web tool for predicting protein solubility from sequence. Bioinformatics 33:3098-3100

Jacobs WM, Shakhnovich El (2017) Evidence of evolutionary selection for cotranslational folding. Proc Natl Acad Sci USA 114:11434-11439

Jimah JR, Salinas ND, Sala-Rabanal M, Jones NG, Sibley LD, Nichols CG, Schlesinger $\mathrm{PH}$, Tolia NH (2016) Malaria parasite CelTOS targets the inner leaflet of cell membranes for pore-dependent disruption. Elife. https://doi. org/10.7554/eLife.20621.001

Kariu T, Ishino T, Yano K, Chinzei Y, Yuda M (2006) CelTOS, a novel malarial protein that mediates transmission to mosquito and vertebrate hosts. Mol Microbiol 59:1369-1379

Katsara M, Minigo G, Plebanski M, Apostolopoulos V (2008) The good, the bad and the ugly: how altered peptide ligands modulate immunity. Expert Opin Biol Ther 8:1873-1884

Khan F, Legler PM, Mease RM, Duncan EH, Bergmann-Leitner ES, Angov E (2012) Histidine affinity tags affect MSP1(42) structural stability and immunodominance in mice. Biotechnol J 7:133-147

Kimchi-Sarfaty C, Oh JM, Kim IW, Sauna ZE, Calcagno AM, Ambudkar SV, Gottesman MM (2007) A "silent" polymorphism in the MDR1 gene changes substrate specificity. Science 315:525-528

Komar AA (2009) A pause for thought along the co-translational folding pathway. Trends Biochem Sci 34:16-24

Komar AA, Lesnik T, Reiss C (1999) Synonymous codon substitutions affect ribosome traffic and protein folding during in vitro translation. FEBS Lett 462:387-391

Kramer EB, Farabaugh PJ (2007) The frequency of translational misreading errors in E. coli is largely determined by tRNA competition. RNA 13:87-96

Kramer G, Boehringer D, Ban N, Bukau B (2009) The ribosome as a platform for co-translational processing, folding and targeting of newly synthesized proteins. Nat Struct Mol Biol 16:589-597 
Laughrea M, Latulippe J, Filion AM, Boulet L (1987) Mistranslation in twelve Escherichia coli ribosomal proteins. Cysteine misincorporation at neutral amino acid residues other than tryptophan. Eur J Biochem 169:59-64

Lee JW, Beebe K, Nangle LA, Jang J, Longo-Guess CM, Cook SA, Davisson MT, Sundberg JP, Schimmel P, Ackerman SL (2006) Editing-defective tRNA synthetase causes protein misfolding and neurodegeneration. Nature 443:50-55

Loftfield RB (1963) The frequency of errors in protein biosynthesis. Biochem J 89:82-92

Loftfield RB, Vanderjagt D (1972) The frequency of errors in protein biosynthesis. Biochem J 128:1353-1356

Manickam N, Nag N, Abbasi A, Patel K, Farabaugh PJ (2014) Studies of translational misreading in vivo show that the ribosome very efficiently discriminates against most potential errors. RNA 20:9-15

Nissley DA, Sharma AK, Ahmed N, Friedrich UA, Kramer G, Bukau B, O'Brien EP (2016) Accurate prediction of cellular co-translational folding indicates proteins can switch from post- to co-translational folding. Nat Commun 7:10341
Parker J (1992) Variations in reading the genetic code. In: Hatfield D, Lee BJ, Robert M (eds) Transfer RNA in protein synthesis. CRC Press, Boca Raton Stansfield I, Jones KM, Herbert P, Lewendon A, Shaw WV, Tuite MF (1998) Missense translation errors in Saccharomyces cerevisiae. J Mol Biol 282:13-24

Thanaraj TA, Argos P (1996) Protein secondary structural types are differentially coded on messenger RNA. Protein Sci 5:1973-1983

Yu XC, Borisov OV, Alvarez M, Michels DA, Wang YJ, Ling V (2009) Identification of codon-specific serine to asparagine mistranslation in recombinant monoclonal antibodies by high-resolution mass spectrometry. Anal Chem 81:9282-9290

Zhang Z, Shah B, Bondarenko PV (2013) G/U and certain wobble position mismatches as possible main causes of amino acid misincorporations. Biochemistry 52:8165-8176

\section{Publisher's Note}

Springer Nature remains neutral with regard to jurisdictional claims in published maps and institutional affiliations.

\section{Submit your manuscript to a SpringerOpen ${ }^{\circ}$ journal and benefit from:}

- Convenient online submission

- Rigorous peer review

- Open access: articles freely available online

- High visibility within the field

- Retaining the copyright to your article

Submit your next manuscript at $\gg$ springeropen.com 